\title{
Challenges in education: The untold story of students in Lanao Kapanglao, Glan, Sarangani province
}

\author{
Omar A. Nedal ${ }^{1 *}$, Marc Gerald O. Alcoriza ${ }^{2}$ \\ ${ }^{1}$ Glan School of Arts \& Trade, Sarangani, Philippines \\ ${ }^{2}$ Danao Elementary School, Panglao, Philippines
}

\author{
Keywords \\ Challenges in education \\ Indigenous students \\ Teacher's difficulties \\ Bla'an \\ Manubo
}

Received: 4 April 2018 Accepted: 30 April 2018 Published: 8 June 2018

\begin{abstract}
This study aimed to investigate the challenges encountered by the indigenous students in assessing quality education in the mountainous area of Lanao Kapanglao. It is located in the Northern part of the Municipality of Glan, 42 kilometers travel and 12 hours hike from the barangay proper of Datal Bukay, Glan Sarangani Province, Philippines. Furthermore, this study also examined the students' demographic profile, ethnic traditions, and daily lifestyle and the difficulties experienced by the teachers assigned in this remote and marginalized area. The respondents of this study were Forty (40) indigenous students from different grade levels. These pupils belong to the one and the most unfortunate and unprivileged pupils in the whole country. Likewise, all students belonged to a very low-income family with a P1000 monthly income and were forced to take absences in school to work on their local farms. Moreover, their school lacks school materials due to the lack of funding and poor accessibility; this condition hampers the students from learning. Even the classroom used was not conducive. Electrification also is a major problem in the community. Hence, the teacher also cannot use their multi-media as an aid in teaching. Overall, their rich indigenous traditions were practiced frequently in their community. On the basis of the findings, recommendations for the government and policymakers are enlisted. These recommendations are aimed to help the students and teachers of Lanao Kapanglao.
\end{abstract}

(C) 2018 The Author(s). Published by TAF Publishing.

\section{INTRODUCTION}

In this 21st Century, educators around the world are busy improving themselves to acquire the 21st century teaching skills to improve their teaching instructions and enhance the learning of their students. Every classroom is equipping with technologies and used multi-media presentations that arouse the interest of the students and become globally competitive. But, don't you know that there are still many schools in the Philippines who are still left behind with this transformation in Education? Yes, these are the schools located in the mountainous area of our country. In addition, the United Nations implement various programs ensuring the brighter future of our children. One of these programs is protecting the right of every child to have a quality education that can develop him holistically and equipped with 21st century skills to be globally competitive individual. Ev- ery child has the right to an education commensurate with his abilities and to the development of his skills for the improvement of his capacity for service to himself and to his fellowmen. In short: Every child has the right to be educated (Malroutu, 2017; Sadik, 2016; United Nations International Children's Emergency Fund, 2010; Yildiz \& Kayili, 2015).

Furthermore, according to Section 1, Article XIV of the Philippine Constitution also known as "No Filipino Child Left Behind Act of 2010", impose upon the state the responsibility "protect and promote the rights of all citizen to quality education to all levels" and "take appropriate steps to make such education accessible to all". It is objective of this bill to allow Filipino children to complete elementary and tertiary education by stabling a systematic program that will ensure that: (1) By 2014, all Filipino children

\footnotetext{
*corresponding author: Omar A. Nedal

†email: marnedal848@gmail.com
} 
of compulsory age must have completed elementary education; (2) By 2018, all Filipinos must have obtained and completed high school education (Kahraman, 2016; Jacolbia, 2016; Nuchso, Tuntivivat, \& Klayklueng, 2016; Senate of the Philippines, 2010; Zarb, 2016).

Likewise, one of the schools that are very left behind our educational system is Lanao Kapanglao Elementary School. It is located in the northernmost part of the Municipality of Glan, a 42 kilometer travel, 50 rivers to cross and 12-hour hike from the barangay proper of Datal Bukay, Glan, Sarangani Province. I stayed two weeks in this area to examine the demographic profile, ethnic traditions and daily lifestyle of the students. In addition, I also investigated the difficulties experienced by the teachers assigned in this remote and marginalized area.

\section{Statement of the Problem}

This study sought to answer the following questions:

1. What is the demographic profile of the indigenous students of Lanao Kapanglao?

2. What are the challenges encountered by the students in accessing education in Lanao Kapanglao?

3. What are the challenges encountered by the teachers in teaching the students in Lanao Kapanglao?

4. What are the needs of the students in Lanao Kapanglao to access quality education in their area?

\section{Scope and Delimitation}

This study was delimited to the challenges encountered by the indigenous students in accessing quality education and the difficulties experienced by the teachers in teaching the students in Lanao Kapanglao. The demographic profile of the students was delimited to age, sex, number of siblings, monthly income, educational background, and occupation of their parents. In addition, this study also wants to investigate the needs of every indigenous students to lessen the difficulties they faced to achieved their dreams in life.

This study was conducted in Lanao Kapanglao Elementary School located at Sitio. Lanao Kapanglao, Brgy. Datal Bukay, Glan, Sarangani Province. The respondents of this study were Forty (40) indigenous students from different grade level of the school and were selected using purposive sampling method. There were Eight (8) teachers interviewed on the difficulties they encountered in teaching in Lanao Kapanglao.

\section{Significance of the Study}

The researcher is hoping for the results and outcomes of this study at its best. Hopefully this may be a great help and will be beneficial to the following person/persons.

\section{Local government}

This study will help them determine the needs of the indigenous students of Lanao Kapanglao and serve as a reference to do projects that help the students to access quality education in their area.

\section{Department of education}

This study will help them identify the status of the indigenous students in Lanao Kapanglao, as well as the difficulties encountered by the students and teachers teaching in this remote area.

\section{Non-Government Organization (NGO)}

It will help them organize community service base on the needs of indigenous students of Lanao Kapanglao such as clothes, school supplies and medicines.

\section{Teachers}

This study will help them exposed the current situation of the indigenous students in Lanao Kapanglao, and exposed/share their experience in teaching the students despite the long distance travel and risk of going to Lanao Kapanglao Elementary School.

\section{Students}

This study will help them voice out their rights of quality education and reveals their difficulties encountered in studying to achieve their dreams in life.

\section{Other researchers}

This study may help future researchers who are conducting re-investigation or parallel researches. They may utilize the results and recommendations at the end of this study as a reference for their respective researches.

\section{Researcher}

This study may help the researcher answer his natural curiosity about the challenges encountered by the students in the remote area of Municipality of Glan especially in Lanao Kapanglao. In addition, this also satisfies the desire of the researcher in showing appreciation to the mountain teachers rendering their outstanding service in the area.

\section{BRIEF REVIEW OF LITERATURE}

The United Nations made a law to protect children from abuse and one of it is the right to have a good Education. Every Child has the right to an education equal with his abilities and to the development of his skills for the improvement of his capacity for service to himself and to his fellowmen. In short, every child has the right to be educated (Meidrina, Mawaddah, Siahaan, \& Widyasari, 2017; Masuo 
\& Cheang, 2017; United Nations International Children's Emergency Fund, 2010).

Furthermore, the right to education entails an inclusive and holistic approach to education, as demonstrated in Article 26 of the UN Declaration of Human Rights: "Education shall be directed to the full development of the human personality and the strengthening of respect for human rights and fundamental freedoms" (United Nations International Children's Emergency Fund, 2010).

Consequently, in policy and practice quality education needs inputs (including adequate investment in public education, safe and healthy schools with adequate infrastructure, facilities and resources and qualified and wellsupported teachers), a comprehensive and inclusive teaching and learning process (including broad curricula focusing on life skills as well as numeracy, literacy and specific subjects, learner centred pedagogies and continuing professional development for teachers) and broad outcomes (including critical thinking and problem-solving capabilities, civic-mindedness and other life skills). The narrow and reductionist view of education, mainly focused on numeracy and literacy and their measurement, is a mistake. This results in a narrow approach to learning, the degrading of other school subjects and essential life skills, values and relations, forcing teachers to 'teach to the test' (Franzini, Caughy, Nettles, \& O'Campo, 2008; Supratman, 2015).

In addition, according to Habito (2014) that one of the hindrances of the students in accessing quality education is poverty. Many of the children in the Philippines want to go to school but they don't have money to buy school supplies, and sometimes their parents ask them to help with the household chores or doing fieldworks in farm to have extra income.

That's why, the mission of the Department of Education in the Philippines is to protect and promote the rights of every Filipino to quality, equitable, culture-based, and complete basic education where students learn in a child-friendly, gender-sensitive, safe, and motivating environment. It is also the duty of the teachers to give quality teaching to the students and be globally competitive (Department of Education, 2010).

\section{Theoretical Framework}

This study is anchored from Arthur, Hall, and Lawrence (1989) theory is an analytical framework that stems from the field of critical legal studies that addresses the racial inequities in society. In this study, the Indigenous students of Lanao Kapanglao which is composed of Blaan and Manobo are very left behind in the educational system of our coun- try. In addition, it also supports by Poverty Theory in Education Spears (2011), this theory explained that students who are the product of poverty have a big chance that can't perform well in school.

\section{METHODOLOGY AND RESEARCH DESIGN}

The researcher used the quantitative-qualitative method of research. The researchers stayed at Lanao Kapanglao for two weeks and studied the difficulties encountered by the students in accessing education and observe their daily living and cultural traditions. In addition, he also experienced the difficulties of the teachers travelling 12 hours hike, and crossing 50 rivers to reach the Lanao Kapanglao Elementary School.

\section{Research Respondents}

The respondents of this study were Forty (40) indigenous students from different grade level of Lanao Elementary School and were selected using purposive sampling method. Only students who are available in the area was observed and interviewed because their homes are far from school with 1-2 hours travel.

\section{Students}

TABLE 1. Students

\begin{tabular}{ll}
\hline \hline Grade Level & Students \\
\hline Grade 1 & 2 \\
Grade 2 & 2 \\
Grade 3 & 4 \\
Grade 4 & 10 \\
Grade 5 & 10 \\
Grade 6 & 12 \\
Total & 40 \\
\hline \hline
\end{tabular}

\section{Teachers}

There were Eight teachers (8) interviewed in Lanao Kapanglao Elementary School.

\section{Research Locale}

This study was conducted in Lanao Kapanglao Elementary School, situated at Sitio. Lanao Kapanglao, Brgy. Datal Bukay, Glan Sarangani Province. It is located in the northernmost part of the Municipality of Glan, a 42 kilometer travel; 12 hours hike and cross 50 rivers from the Barangay proper of Datal Bukay. This is the favourite spot of New People's Army or NPA as their resting place because it is far from town and the AFP can't easily patrol in this area. This place very cold even day, and it has unique beauty because of the Lake Lanao at its center where it is a possible tourist. 


\section{Research Instrument}

The researcher used a self-made questionnaire and validated by master teachers of Glan School of Arts and Trades suited for the objectives of the study.

\section{Data Gathering Procedure}

After seeking the approval from the School District Superintendent of Division of Sarangani, the teacher-researcher started the conduct of this study. The researcher join the climb with the teachers assigned in Lanao Kapanglao. He stayed in this area for two weeks and interviewed the Forty (40) respondents and their answers were recorded and analyze using data analysis approach.

\section{RESULTS AND DISCUSSION}

The following are the results and analysis done from the data.

\section{Demographic Profile of the Indigenous Students}

TABLE 2. Tribes of indigenous students in Lanao Kapanglao

\begin{tabular}{lll}
\hline \hline Age & Frequency & Percentage \\
\hline Manobo & 158 & 35.00 \\
Blaan & 292 & 65.00 \\
Total & 450 & 100.00 \\
\hline \hline
\end{tabular}

According to the teachers of Lanao Kapanglao Elementary School, there are two tribes present in Lanao Kapanglao, Blaan and Manobo. The Students in Lanao Kapanglao Elementary School have a total of 450 students from different Sitios of Lanao Kapanglao. According to data gathered by the teachers assigned in this area, $35 \%$ of their students were Manobo and 65\% were Blaan. The indigenous people living in this area are still practicing their cultures like dances, traditions and rituals.

TABLE 3. Age of indigenous students

\begin{tabular}{lll}
\hline \hline Age & Frequency & Percentage \\
\hline $8-10$ & 4 & 10.00 \\
$11-13$ & 19 & 47.50 \\
$14-16$ & 12 & 30.00 \\
$17-19$ & 5 & 12.50 \\
Total & 40 & 100.00 \\
\hline \hline
\end{tabular}

Table 3 reveals that almost of the students are over-age for their grade level. The respondents of this study have an age range of 8-10years old (10\%), 11-13years old (19\%), 14-16years old (30\%), 17-19 years old (12.50\%). According to Department of Education (2010), students who will enter 1st grade should have an age range of 6-7 years old and end their 6th grade with an age range of 11-12 years old.

TABLE 4. Sex of indigenous students

\begin{tabular}{lll}
\hline \hline Sex & Frequency & Percentage \\
\hline Male & 16 & 40.00 \\
Female & 24 & 60.00 \\
Total & 40 & 100.00 \\
\hline \hline
\end{tabular}

Table 4 shows that majority of the respondents were female with a percentage of $60 \%$. Only $40 \%$ of the respondents were male.

TABLE 5. Number of siblings

\begin{tabular}{lll}
\hline \hline Age & Frequency & Percentage \\
\hline $3-5$ & 18 & 45.00 \\
$6-8$ & 12 & 30.00 \\
$9-11$ & 5 & 12.50 \\
$12-14$ & 4 & 10.00 \\
$15-17$ & 1 & 2.50 \\
Total & 40 & 100.00 \\
\hline \hline
\end{tabular}

Table 5 shows that families in Lanao Kapanglao have a big number of siblings. The numbers of siblings present in the respondents of this study are 3-5 (45\%), 6-8 (30\%), 9-11 (12.5\%), 12-14 (10\%) and 15-17 (2.5\%). The researcher noted that one of the respondents in this study has 17 siblings. This student seldom goes to school because he was forced to take care of his siblings and sometimes work on their local farms.

TABLE 6. Monthly income of the family of the students

\begin{tabular}{lll}
\hline \hline Age & Frequency & Percentage \\
\hline P1000 and above & 32 & 80.00 \\
P801-P1000 & 5 & 12.50 \\
P500- P800 & 1 & 2.50 \\
P500 and below & 2 & 5.00 \\
Total & 40 & 100.00 \\
\hline
\end{tabular}

Table 6 reveals the monthly income of the family of the indigenous students. The highest monthly income of the family of the respondents is $\mathrm{P} 1000$ and above with a percentage of $80 \%$, followed by P801-P1000 (12.5\%), P500-P800 (2.5\%) and P500 and below (5\%). Because of poverty, most of students enrolled in Lanao Elementary School eat their meal once a day. They are collecting fruits and wild crops while on their way going to school, that's why, they are sometimes late in their class. 
TABLE 7. Educational background of parents and students

\begin{tabular}{lllll}
\hline \hline Grade Level & Father & \multicolumn{3}{l}{ Mother } \\
\cline { 2 - 5 } & $\boldsymbol{F}$ & $\mathbf{\%}$ & $\boldsymbol{F}$ & $\mathbf{\%}$ \\
\hline Grade 1 & 36 & 90.00 & 25 & 62.50 \\
Grade 2 & 3 & 7.50 & 7 & 17.50 \\
Grade 3 & 1 & 2.50 & 5 & 12.50 \\
Grade 4 & 0 & 0.00 & 1 & 2.50 \\
Grade 5 & 0 & 0.00 & 1 & 2.50 \\
Grade 6 & 0 & 0.00 & 1 & 2.50 \\
Total & 40 & 100.00 & 40 & 100.00 \\
\hline \hline
\end{tabular}

Table 7 shows that the parents of Indigenous students in Lanao Kapanglao have low educational background. Most of the fathers only reached Grade 1 with a percentage of $90 \%$ and only $2.5 \%$ of them reach Grade 3 . Likewise, most of the mothers also only attended Grade 1 with a percentage of $62.50 \%$ and only $2.5 \%$ reached the 6 th Grade in primary level. This is the reason why all of their parents can't help the students in their studies. Their parents also can't view the importance of education of their children as one of the stepping stone to achieve the dreams of their child. Instead, they orient their child to work hard in their farms, to gain money and buy something to eat in everyday living.

TABLE 8. Occupation of parents

\begin{tabular}{lllll}
\hline \hline Grade Level & Father & \multicolumn{3}{l}{ Mother } \\
\cline { 2 - 5 } & $\boldsymbol{F}$ & $\mathbf{\%}$ & $\boldsymbol{F}$ & $\mathbf{\%}$ \\
\hline Farmer & 40 & 100.00 & 10 & 25.00 \\
None & 0 & 0.00 & 30 & 75.00 \\
Total & 40 & 100.00 & 40 & 100.00 \\
\hline \hline
\end{tabular}

Table 8 shows that the family of the respondents make farming their number one source of income where all of their fathers are farmer and $25 \%$ of the mother are also farmer. There are $75 \%$ of mothers of the respondents who are not working in their local farms, but instead they are taking care of their homes and their children. The crops that they are planting are corn, rice, sweet potatoes, banana, and cassava. If there is no harvest, they seldom eat their meals three times a day. These crops are also the "baon" of the students in school, thus students in Lanao Kapanglao suffer from malnutrition and lack of vitamins.

Table 9 shows the challenges encountered by the indigenous students in accessing quality education in Lanao Kapanglao. The researcher interviewed the Forty (40) respondents and their answers were recorded and analyze using data analysis approach. The researcher also highlighted some answers of the students. As a result of the interviews, this data was gathered.

TABLE 9. Challenges encountered by the indigenous students in accessing quality education in Lanao Kapanglao

\begin{tabular}{ll}
\hline \hline Challenges Encountered & Percentage \\
\hline 1. Distance from home to school & $95 \%$ \\
2. Lack of School Supplies & $93 \%$ \\
3. Absenteeism due to work & $100 \%$ \\
4. No proper meals every day & $97 \%$ \\
5. Lack of classroom facilities & $100 \%$ \\
6. Lack of proper dresses & $67 \%$ \\
7. No lights at night to study their lessons & $100 \%$ \\
\hline \hline
\end{tabular}

\section{Difficulties with the Distance from their Home to School- 95\%}

The students travel 1-2 hours to reach the school from their sitios.
S1: "Layo kaayo among ginalakaw para maabot amung skwelehan, kapoy kaau" ("We walk too far to reach our school, so tired") 
S2: "Layo kaayo ang iskwelahan, mag labang pamig sapa, upat kabuok, kung taob, dle mi makalabang, dile nalang mi magsulod sa skwelahan" ("Our school is too far, we cross four rivers, if it is flooding, we can't attend to our class"). S3: "Hadlok kaayo usahay sa dalan, maong daghan jd mi mag skwela, usahay naa bitin sa dalan' ('Sometimes were afraid while on our way to school, that's why we go together with my friends, and sometimes we encounter snakes in our way")

S4: "Lisod kaau ang dalan basta ulan, lapok kaayo, mahugawan among sanina, ginadala namu among tsinelas kay basig maputol, pero sakit kaayo among tiil sa tunok" ('It's hard to walk if it is raining, so muddy, sometimes our clothes get dirty and carry our slippers so that it will not be damage, but the thorns in our way is very painful to our feet")

\section{Lack of School Supplies - 93\%}

S1: "Wala koy mga gamit sa skwelahan, manghiram lang ko kay Ma'am. Mangayo kog papel ug lapis para makasulat ug letters" ("I have no school supplies; I just borrowed to my teacher. Sometimes I ask for paper and pencil to write letters")

S2: "Wala koy bag, ginabutang nako akung papel ug baon sa cylophane, gusto lang naku mu iskwela". ('I have no school bag, I just put my papers and "baon" in plastic bags, because I want to go to school"

S3: "Wala nakuy notebook kay naa nay sulat tanan, maminaw nalang ko kay Maam kay para makabalo" ('I have no notebook because all of the pages of my last notebook is already full, I will just listen to the lecture of my teacher for me to learn").

\section{Absenteeism due to Work - $\mathbf{1 0 0 \%}$}

S1: "Ginapa absent ko ni papa sa iskwelahan kay magtabang ko sa among uma, kay mangharvest mi para naa mi kaunon (Grade 6 student)" ("My father forced me to be absent in school to help in our farm in the harvest so that we have something to eat")

S2: "Ingun ni mama mag absent ko kay magbantay ko sa akung manghud, kay walay mabilin sa balay, kay mulakaw sila ni papa sa bukid (Grade 2 student)". ("My mother told me to absent in school to take care of my younger sister and to our house, because they will go to the farm with my father").

\section{No Proper Meals Every Day - 97\%}

S1: "Wala ko gapamahaw mag sulod sa iskwelahan kay wala mi pagkaon sa balay, mangita lang mi pagkaon sa dalan". ('I have no breakfast before going to school because we have no food in our house, we will look for foods while in our way to school")

S2: "Usahay magsakit akung tiyan basta walay kaon, malipong ko, pero maluoy man si Ma'am sa akoa, hatagan ko niyag biscuit" ("Sometimes I suffer from stomach-ache and fainted because I have nothing to eat, but my teacher give me biscuit")

\section{Lack of Classroom Facilities-100\%}

S1: "Guba-guba among room, usahay didto mi mag room sa among simbahan". ("Our classroom has much damage, and sometimes we use our church as our classroom")

S2: "Gamay kaau among bangko, usahay akung classmate magyaka nalang sa yuta para himuon nga lamesa ang bangko". (We have only small number of chairs and sometimes, my classmates sits on the ground and make their chair their table)

\section{Lack of Proper Dresses - 67\%}

S1: "Gamay kaau akung sanina, murag tulo lang kabuok tapos daan na kaayo, gina balik-balik lang naku para naa koy masuot" (I have only a few clothes, three I think, and it is very old but still I used it so that I have something to wear everyday)

S2: "Akung mga sanina gamay na kaayo sa akoa, pero ginasuot gihapon naku kay wala man mi ikapalit" ("My clothes are already too small to fit on me, but I still wear it because we have nothing to buy new dress")

\section{No Lights at Night to Study their Lessons $\mathbf{- 1 0 0 \%}$}

S1: "Sayo mi gatulog basta gabei kay wala man mi suga, dile pud mi maka study" (We sleep early at night because we have no light, that's why we can't study our lessons").

Table 10 shows the challenges encountered by the teachers in teaching students in Lanao Kapanglao Elementary School. Number 1 challenge for the teachers assigned in this remote area is the distance of school from the town proper of Glan (100\%). A 42 kilometer hike from barangay proper of Datal Bukay, 12 hours walking and climbing in the mountains, crossing 50 rivers with big stones, plus the risk of snakes and other wild animals make the teacher faced many challenges before reaching the school. They are the real heroes; they take the risks for the sake of the students, to impart knowledge and skills for the indigenous students. They spent a month in teaching in this area before they can go home and sometimes they cry at night, especially the female teachers, because they miss their families. 
TABLE 10. Challenges encountered by the teachers in teaching students in Lanao Kapanglao elementary school

\begin{tabular}{ll}
\hline \hline Challenges Encountered & Percentage \\
\hline 1. Distance of school from the town of Glan & $100 \%$ \\
2. Risk from New People's Army (NPA) & $100 \%$ \\
3. Absenteeism of the students & $100 \%$ \\
4. Poor Nutrition & $100 \%$ \\
5. Lack of instructional materials & $100 \%$ \\
6. Lack of Classrooms & $100 \%$ \\
7. No electricity for multimedia presentations & $100 \%$ \\
\hline \hline
\end{tabular}

Furthermore, the risk from New People's Army or NPA (100\%) makes their climb difficult and complex for their safety. Lanao Kapanglao is known as the resting place of NPA because it is the northernmost part of Glan where the army can't easily patrol. The risk from bandits to become a hostage robbed or raped is taken by our teachers in Lanao Kapanglao.

In addition, absenteeism of the students (100\%) is also the problem of the teachers, because students in this area are force to work in their local farms or take care of their younger siblings. Likewise, our teachers suffer from poor nutrition (100\%), because they only eat noodles and canned goods that they bring on their travel. They are not accepting foods from the villagers in the area to avoid the risk of being poisoned or affected by "Kulam" or folk magic.
Moreover, lack of instructional materials (100\%) and classrooms $(100 \%)$ is one of the major problems of the teachers. They can't teach well because on unavailability of reading materials to the students and often used old books. The classroom also is not conducive in learning; there are no walls and lack of chairs. Sometimes, they used the Baptist church in the area to become their temporary classroom. Consequently, there is no electricity $(100 \%)$ in Lanao Kapanglao, that's why; they can't use multi-media in teaching. They use solar panel flashlight as their light during night. They sleep early around $7 \mathrm{pm}$ in the evening. The teachers in Lanao Kapanglao are the heroes of the indigenous students, because despite of many challenges they encounter, they take all the risk just for them.

TABLE 11. Needs of the students in Lanao Kapanglao elementary school

\begin{tabular}{ll}
\hline \hline Challenges Encountered & Percentage \\
\hline 1. They need safe and proper road from their homes to school & $100 \%$ \\
2. They need proper dresses & $100 \%$ \\
3. They need school supplies & $100 \%$ \\
4. They need healthy foods & $100 \%$ \\
5. They need medicines and vitamins & $100 \%$ \\
6. They need secondary level in Lanao Kapanglao & $100 \%$ \\
\hline \hline
\end{tabular}

Table 11 shows the needs of the students in Lanao Kapanglao Elementary School to access quality education. They need safe and proper road from their homes to school (100\%), to avoid them from danger like snakes and other wild animals. In addition, they also need proper dresses $(100 \%)$ to make them comfortable and away from sickness. They also need school supplies (100\%) to improve their learning in school, so that they can take notes, write and draw. They need healthy foods $(100 \%)$ so that they can eat healthy meals everyday and avoid malnutrition, and lastly, they need medicines and vitamins because they are suffering from nutrition deficiency and strong from sickness. And lastly, students in this area need secondary level of educa- tion so that they can continue their study, because if there is only primary school, they will not achieve their dreams in life and their knowledge is only limited on 6th Grade.

\section{CONCLUSION}

Based on the findings, the following conclusions were made: 1. The indigenous students of Lanao Kapanglao belong to a very poor and unprivileged family.

2. The indigenous students of Lanao Kapanglao faced many challenges to access quality education in their area.

3. The teachers faced many difficulties in teaching the students in Lanao Kapanglao, but they take the risk for the welfare of the students.

4. The indigenous students of Lanao Kapanglao have many 
basic needs to have quality education such as proper road, dresses, healthy foods, vitamins, school supplies and need of secondary level of education.

\section{limitationsa and recommedndations}

Like any other study, this study has limitations too. Consequently, further similar investigations are encouraged by the researcher to further the findings of this study.

Based on the findings and conclusions, the following recommendations were made.

1. The Government should give support and attention to lessen the difficulties encountered by the students in Lanao
Kapanglao.

2. The Government should give the needs of the students as noted in the result of this study.

3. The teachers assigned in Lanao Kapanglao should be awarded and increase their salary because of the risk that they take for the welfare of the students in the area.

4. The Department of Education should focus on helping the schools in remote areas because they are very left behind with the development the in education of our country and making the gap bigger for the students in this remote area and the students in town.

\section{REFERENCES}

Arthur, M. B., Hall, D. T., \& Lawrence, B. S. (1989). Handbook of career theory. In Irving B. Weiner (Ed.), Developmental psychology. Hoboken, NJ: John Wiley \& Sons, Inc.

Department of Education. (2010). Department of education mission and vission, core values and mandates. Retrieved from https://goo.gl/gvVHZk (accessed on 30 March, 2018)

Franzini, L., Caughy, M. O., Nettles, S. M., \& O'Campo, P. (2008). Perceptions of disorder: Contributions of neighborhood characteristics to subjective perceptions of disorder. Journal of Environmental Psychology, 28(1), 83-93. doi:https:// doi.org/10.1016/j.jenvp.2007.08.003

Habito, C. F. (2014). A culture of poverty. Retrieved from https://goo.gl/Hzy5VS (accessed on 13 November, 2017)

Jacolbia, R. B. (2016). Future educators' perceptions on technology and livelihood education status and development of work skills. Journal of Advances in Humanities and Social Sciences, 2(2), 85-91. doi:https://doi.org/10.20474/jahss-2.2.3

Kahraman, C. (2016). Role of geography in environmental education. International Journal of Humanities, Arts and Social Sciences, 2(4), 121-125. doi:https://doi.org/10.20469/ijhss.2.20001-4

Malroutu, Y. L. (2017). Enhancing student learning experience in blended classroom teaching. Journal of Advances in Humanities and Social Sciences, 3(6), 324-331. doi:https://doi.org/10.20474/jahss-3.6.4

Masuo, D., \& Cheang, M. (2017). Disconnect between parents' values for saving and actual savings behavior: Impact on children's education and financial decision-making. Journal of Advances in Humanities and Social Sciences, 3(6), 332-339. doi:https://doi.org/10.20474/jahss-3.6.5

Meidrina, T., Mawaddah, S. N., Siahaan, F. M. M., \& Widyasari, P. (2017). The relationship between teacher efficacy and attitude towards inclusive education in private elementary school: A study based on teaching experiences. Journal of Advances in Humanities and Social Sciences, 3(3), 124-134. doi:https://doi.org/10.20474/jahss-3.3.1

Nuchso, N., Tuntivivat, S., \& Klayklueng, P. (2016). The effect of learning organization and servant leadership on childcentered teaching behavior with the mediating role of knowledge sharing in education of Chanthaburi Diocese schools. International Journal of Humanities, Arts and Social Sciences, 2(5), 181-188. doi:https://doi.org/10.20469/ijhss.2 .20004-5

Sadik, F. (2016). Investigating primary school teachers' views about their classroom management behavior. Journal of Advances in Humanities and Social Sciences, 2(2), 76-84. doi:https://doi.org/10.20474/jahss-2.2.2

Senate of the Philippines. (2010). Senate bill of the 14th senate congress. Retrieved from https ://goo .gl/pqhEip (accessed on 30 March, 2018)

Spears, D. (2011). Economic decision-making in poverty depletes behavioral control. The BE Journal of Economic Analysis \& Policy, 11(1), 45-60. doi:https://doi.org/10.2202/1935-1682.2973

Supratman, L. P. (2015). A case study of classroom seating arrangement to promote students' communication and interactivity in Telkom University. International Journal of Humanities, Arts and Social Sciences, 1(3), 130-133. doi:https:// doi.org/10.20469/ijhss.20005-3

United Nations International Children's Emergency Fund. (2010). The rights of every child. Retrieved from https : //goo.gl/ fasM4x (accessed on 21 February, 2018) 
Yildiz, F. U., \& Kayili, G. (2015). Examining the effects of computer-assisted preschool educational activities on children's intuitive mathematical ability. Journal of Advances in Humanities and Social Sciences, 1(1), 1-8. doi:https://doi.org/ 10.20474/jahss1.1.1

Zarb, N. (2016). Stories from the middle: Perceptions of the roles of curriculum development managers in a Maltese further education organization. Journal of Advanced Research in Social Sciences and Humanities, 1(1), 18-29. doi:https:// doi.org/10.26500/jarssh-01-2016-0103 